\title{
Impact of self-perceptions, social norms, and social capital on nascent entrepreneurs: a comparative analysis by level of economic development in Latin American countries
}

\author{
Gustavo Barrera-Verdugo* (1)
}

\section{${ }^{*}$ Correspondence:} gbarrera@udla.cl Faculty of Engineering and Business, Universidad de Las Américas, Manuel Montt 948, Providencia, Santiago, Chile

\begin{abstract}
The impact of individual psychological and social conditions on participation in entrepreneurship has been widely studied. However, little is known about these variables' comparative influence on the development of nascent ventures in countries with different levels of gross domestic product per capita. This research compares the effects of self-perceptions, perceived subjective norms, and first-hand connections with entrepreneurs on participation in nascent entrepreneurs in Latin America. Logistic regressions are performed and the resulting coefficient magnitudes and pseudo- $R^{2}$ values compared for the populations of 11 countries in this region. The evidence reveals heterogeneity in the effect of these psychological and social attributes on nascent ventures' creation process, conditional on different levels of gross domestic product per capita. Notably, higher economic development is positively related to a greater influence of these perceptual and social variables. The findings enhance understanding of the effects of key variables from theories of entrepreneurial behaviour, incorporating economic development level as a new determinant. In addition, the results could guide programmes aimed at strengthening entrepreneurship in Latin America by supporting the adaptation of efforts to support nascent entrepreneurship according to the influence of perceptual and social variables in different countries.
\end{abstract}

Keywords: Economic development, Nascent entrepreneurship, Self-perceptions, Social capital, Social norms

\section{Introduction}

Entrepreneurship is defined as "the creation of new organizations and is viewed as a context-dependent social process" (Low \& Abrahamson, 1997, p. 435) and "a social process by which opportunities for profitable exchange are pursued” (Martinez, 2020, p. 2). Entrepreneurship has gained high importance among Latin American countries in recent years (Sanabria Rangel et al., 2015) due to its well-documented contribution to economic development, job creation, and poverty reduction (Ács et al., 2016; Stam et al., 2006). Therefore, several programmes have been implemented to promote

(c) The Author(s), 2021. Open Access This article is licensed under a Creative Commons Attribution 4.0 International License, which permits use, sharing, adaptation, distribution and reproduction in any medium or format, as long as you give appropriate credit to the original author(s) and the source, provide a link to the Creative Commons licence, and indicate if changes were made. The images or other third party material in this article are included in the article's Creative Commons licence, unless indicated otherwise in a credit line to the material. If material is not included in the article's Creative Commons licence and your intended use is not permitted by statutory regulation or exceeds the permitted use, you will need to obtain permission directly from the copyright holder. To view a copy of this licence, visit http:// creativecommons.org/licenses/by/4.0/. 
entrepreneurial activity in this region; these initiatives are meant to provide business support services and access to financing, support growth in demand, and strengthen the entrepreneurial culture (OECD, 2016).

Various research studies have analysed the personal qualities of entrepreneurs (Krueger \& Carsrud, 1993; Solesvik, 2017; Van Ness \& Seifert, 2016) and the conditions of the entrepreneurial ecosystem (e.g., Mason \& Brown, 2014; Roundy et al., 2018) that impact entrepreneurial intent and participation in the early stages of entrepreneurship. Regarding personal qualities, there are three characteristics with a recognized effect on entrepreneurship's development: self-efficacy (e.g., Boyd \& Vozikis, 1994; Hsu et al., 2019; Wilson et al., 2007), defined as the perception of one's capability of obtaining desired outcomes (Bandura, 2001); perceptions of the social appreciation of entrepreneurship (e.g., Bellò et al., 2018; Levie et al., 2010; Littlewood \& Holt, 2018); and the availability of networks or social capital. (Lin, 2017). These variables have been incorporated into theoretical models to explain entrepreneurial behaviour, such as the theory of planned behaviour (Ajzen, 1991).

There is substantial evidence supporting the influence of self-efficacy, subjective norms linked to social valuation of entrepreneurship, and social capital on attitudes and behaviours related to new business creation (e.g., Bizri, 2017; Fenech et al., 2019; Neumeyer et al., 2019; Piperopoulos \& Dimov, 2015). However, the magnitude of such influences on nascent entrepreneurship has not been compared among Latin American countries with different gross domestic product (GDP) levels. This knowledge gap is significant because although Latin American nations share values, a language, and government systems, they also face diverse environments and particularities in their national cultures (Inglehart \& Carballo, 2008); moreover, they differ in their access to information technologies, economic development, and poverty levels (Rodríguez \& Riofrío, 2017).

Because no extensive comparative analysis has been conducted in Latin America in this regard, the objective of this research is to contrast the impact of self-perception, perceived subjective norms, and connections with other entrepreneurs on nascent ventures. In particular, this study compares the effect of these personal attributes in countries with variations in GDP, specifically Argentina, Brazil, Chile, Colombia, Ecuador, Guatemala, Mexico, Peru, Puerto Rico, and Uruguay. Nascent entrepreneurs are persons engaged in activities intended to culminate in a viable new firm (Davidsson, 2006; Reynolds, 1994); this group is analysed because of the positive relationship between venture creation and recognition of opportunities (Lundberg \& Rehnfors, 2018) as well as new entrepreneurs' significant resource requirements (Davidsson, 2006) and challenges with new venture survival (Ucbasaran et al., 2013). Indeed, a substantial percentage of new ventures do not survive their initial phases in Latin America (Gómez Legarda, 2019).

The current study evaluates the Adult Population Survey (APS) dataset from Global Entrepreneurship Monitor (GEM). This information source contains data obtained in 2015 and is publicly accessible. Quantitative analysis is carried out through logistic regressions, the Chi-square test estimated to measure goodness of fit, $p$-values used to assess the significance of the regressions' odds ratios, and the pseudo- $R^{2}$ indicator analysed to evaluate the percentage of the variance in the dependent variable explained by the independent variables. 
This research allows us to validate or refute existing knowledge on the importance of self-efficacy, perceived subjective norms, and social capital in Latin America from a comparative perspective. In particular, this work extends the understanding of these variables' effects in countries with different levels of economic development, measured through GDP per capita. This perspective fills an information gap, shedding new light on the relationship between economic growth and the importance of these attributes as drivers of the creation of new businesses. In other words, the findings enhance understanding of the effects of key variables from theories of entrepreneurial behaviour conditional on the economic development level of Latin American countries.

This research might also guide implementation of programmes to strengthen entrepreneurship in Latin American countries: for instance, resources could be allocated to support activities to enhance entrepreneurs' self-perception, contribute to the social validation of entrepreneurship, or develop entrepreneurs' networks. The evidence highlights the usefulness of mentoring programmes, projects that foster development of entrepreneurs' networks, and communication campaigns that positively impact social perceptions of entrepreneurship in a country. Moreover, efforts to support entrepreneurship could be adapted to the influences of perceptual and social variables in each country.

\section{Theoretical background}

\section{Self-perception}

Self-concept theory deals with individuals' perceptions of themselves, such as their selfknowledge and attitudes or emotions related to the self (Greenwald et al., 2002). In this vein, self-efficacy is a more limited component of one's self-concept related to personal beliefs surrounding one's capabilities of achieving proposed goals (Bandura, 2001; Chen et al., 2001). One of the fields in which the notion of self-efficacy has acquired high relevance is entrepreneurship (Wang et al., 2016); in this framework, the construct is associated with beliefs related to personal capabilities that allow one to successfully fulfil an entrepreneur's roles (McGee et al., 2009; Newman et al., 2019). Chen et al. (1998) recognized five dimensions of entrepreneurial self-efficacy related to entrepreneurial intentions and success; these dimensions are linked to personal capabilities associated with marketing, innovation, management, risk-taking, and financial control.

Self-efficacy has been widely associated with the intention to create ventures (Asante \& Affum-Osei, 2019; Boyd \& Vozikis, 1994), the success of new businesses (McGee \& Peterson, 2019; Wang et al., 2016), and particular factors that facilitate entrepreneurial success, such as a passion for creating new ventures (Cardon \& Kirk, 2015). Additionally, several attributes that affect the level of individual self-efficacy have been analysed (Obschonka \& Stuetzer, 2017; Wang et al., 2016), among them gender (e.g., Nowiński et al., 2019), educational level (Wilson et al., 2007) and participation in entrepreneurship training programmes (Peterman \& Kennedy, 2003; Piperopoulos \& Dimov, 2015). In Latin America, a significant number of studies analysing the effect of self-efficacy on students' entrepreneurial intentions have been published (e.g., Aguirre Mas \& Vauro Desiderio, 2009), reaffirming the positive relationship between a good self-perception and the intention to create new ventures (e.g., Guzmán-Alfonso \& Guzmán-Cuevas, 2012; Lecuna et al., 2017). 
A factor in the level of self-efficacy and its effects on business is the culture of the population overall. In cultural contexts associated with a low degree of institutional collectivism and high individualism, entrepreneurial self-efficacy tends to have more powerful effects (Schmutzler et al., 2019). The same outcome can be discerned in societies characterized by a low fear of uncertainty, where the impact of self-efficacy on business decision-making is intensified (Wennberg et al., 2013). Additionally, in countries with more traditional gender roles, such as Spain, being male is related to showing higher levels of business self-efficacy (Mueller \& Conway Dato-on, 2013).

Complementarily, self-efficacy has been linked to cultural traits and economic development. Pinillos and Reyes (2011) point out that in agricultural societies with low economic development, production is based on family production units, and consequently, there is a culture of the collectivist type; in contrast, industrialized countries with higher incomes have a culture with a greater predominance of individualism. Likewise, it has been recognized that economic development is related to changes in people's worldviews (Inglehart \& Welzel, 2005); for example, China and South Korea have undergone a cultural transformation in recent decades in association with their higher economic development (Li et al., 2018; Onder \& Nyadera, 2019). Regarding differences in self-perceptions due to economic growth, Loughnan et al. (2011) documented greater increases in self-esteem in societies with higher income inequality, noting that this result indicates that macro-social differences in the distribution of economic goods are linked to microsocial processes regarding self-perception.

Due to the recognition in previous research on other continents of the impact of culture on self-efficacy and economic development, it is possible to suggest that countries with different economic development levels in Latin America should display variations in the influence of self-efficacy on creating nascent enterprises. Therefore, the following hypothesis is put forward:

H1: The impact of self-perceptions on nascent ventures varies in magnitude among Latin American countries, with different levels of economic development.

\section{Subjective norms}

The concept of subjective norms is embedded in the psychological theory of planned behaviour as perceived social pressure to perform or not perform an action (Ajzen, 1991). In the current context, subjective norms are associated with individuals' normative beliefs about entrepreneurship, which affect their ventures' activities. Two general types of subjective norms have been distinguished: first, descriptive norms, which are acquired from observing other peoples' actions, and second, prohibitive norms, which relate to the expectations for action that other people have validated (Manning, 2009).

Previous publications have supported that subjective norms influence people's attitudes and decisions (Krueger et al., 2000), with a strong correlation shown between people's normative beliefs and behaviours. In this vein, Bicchieri and Muldoon (2011) argued that beliefs, expectations, and common knowledge are central supports in developing a philosophical view of social norms. In the entrepreneurial context, social pressures affect people's intentions and actions regarding business creation (e.g., de Vries et al., 1988; Utami, 2017). Specifically, studies based on the theory of planned behaviour 
(Ajzen, 1991) have incorporated subjective norms as a variable that impacts entrepreneurial intentions (e.g., Al-Jubari et al., 2019; Krueger \& Carsrud, 1993); this theory predicts an effect of subjective norms on personal willingness to create a new business (Kautonen et al., 2013). In the Latin American context, the evidence for this effect is still incipient; an unusual example is a study published by Krauss et al. (2018) that analysed entrepreneurial intention with reference to the theory of planned behaviour with responses from several Latin American universities.

It has been suggested that subjective norms vary between different cultures and favour entrepreneurship in some cultures more than others (Stephan \& Uhlaner, 2010). Additionally, it has been supported that culture can affect the influence of social norms on people's attitudes; that is, in some cultures, social influence is more important for the population (Moriano et al., 2012). Likewise, gender roles in a culture guide men's and women's entrepreneurial attitudes and actions; in particular, it has been recognized that subjective norms tend to encourage male entrepreneurship more than female entrepreneurship (Santos et al., 2016). In recent years, research has tried to deepen the analysis of these norms in the contexts of Africa and Asia (e.g., Alshebami et al., 2020; Ephrem et al., 2019) by, for example, identifying the incidence of social norms in the Islamic world (e.g., Chandran \& Aleidi, 2018; Rehan et al., 2019).

Moreover, social norms are linked to economic development. Palivos (2001) related social norms to fertility, family size, and economic development. Pinillos and Reyes (2011) emphasized that social norms, through general trends towards collectivism or individualism, affect people's self-interest, common interests, consumption, and work and that these trends also affect economic activity. Fafchamps (2011) argued that economic development implies a structural transformation on task assignation, changing from productive self-sufficiency to specialization with the exchange of products; he also documented that this task transformation depends on changes in people's social norms and attitudes. Recently, La Ferrara (2019) stated that personal aspirations are related to economic development and that social stereotypes and norms affect people's aspirations.

Previous evidence has indicated that subjective norms are more conducive to entrepreneurship in some cultures and that social norms affect countries' economic development. Consequently, this research suggests that cultural differences among Latin American countries related with their level of economic development, should condition the impact of social influence on new business creation. The following hypothesis is thus proposed:

H2: The impact of subjective social norms on nascent venture varies among Latin American countries with different levels of economic development.

\section{Social capital and networking}

Several authors have recognized the importance of contacting other entrepreneurs to obtain new business ideas, found start-ups, and maintain successful business operations (e.g., De Carolis \& Saparito, 2006; Farooq et al., 2018; Kim \& Aldrich, 2005). This factor has been studied mainly through two concepts: first, from the perspective of social capital, and second, based on the evaluation of contact networks. Social capital is understood as a resource associated with social relations that can deliver certain benefits, such 
as higher possibilities of entrepreneurship success (Buttice et al., 2017). The usefulness of the social capital perspective has been supported by several authors, such as Neergaard and Madsen (2004) in Denmark and Batjargal (2003) in Russia.

Social networks refer to interactions and relationships between different persons (Banks \& Hengartner, 2008). Social network theory is based on two central premises: that entrepreneurs' resources are scarce and that they acquire them through networks of contacts (Ostgaard \& Birley, 1996). This means that an individual must achieve credibility to convince other people with whom they are close to take risks in favour of the success of his/her company (Stuart \& Sorenson, 2005). The social capital and social network perspectives do not contradict each other; rather, they both describe the importance of social interactions in entrepreneurship (Lin, 2017).

More recently, the study of networks and social capital has focused on priority segments of the population, such as female entrepreneurs, home microenterprises, and entrepreneurs in poverty. In this regard, Neumeyer et al. (2019) recognized the disadvantages of women in terms of social capital is comparison with men, Nguyen and Nordman (2018) studied the positive effects of social networks on household microenterprises, and Wu and Si (2018) supported the benefits of social capital among poor entrepreneurs.

Moreover, previous research has posited that there is heterogeneity in social capital and social networks by people's nationality or culture. Foley (2008) documented the disadvantages of social capital among indigenous entrepreneurs from Australia. Tata and Prasad (2015) highlighted the benefits of social capital among immigrant entrepreneurs in terms of access to financial resources and relevant information. Likewise, Batjargal (2007) found differences in the development of networks between entrepreneurs in Russia and China.

The impact of social capital and networks has also been studied in Latin American countries. Fornoni and Foutel (2004) highlighted universities' role in strengthening social capital in Argentina and the positive effect of social capital on the development of entrepreneurship in this country. Madrigal et al. (2012) recognized the contribution of entrepreneurs' social capital to a business cluster in Jalisco, Mexico. Additionally, Bravo and Quijano (2015) distinguished different social capital dimensions in business incubation processes in Colombia, and more recently, Barrera and Rodríguez (2017) argued that social networks enhance young Colombian entrepreneurs' business success. Although these studies support the contributions of social capital and networks to the development of entrepreneurship, a comparative analysis of Latin American countries on this subject's effect is not currently available.

The relationship between social capital and economic development has also been supported in previous research. Trigilia (2001) argued that social capital could generate confidence and information, which help economic growth, and that this situation occurs mostly in economies with higher flexibility. Midgley and Livermore (1998) stated that community social workers can promote local economic development by implementing projects that mobilize social capital and enhance the local population's material wellbeing. Christoforou (2017) stated that social capital is crucial for creating shared values and identities, inclusive networks, participatory governance structures, and democratic decision-making mechanisms to foster economic growth in rural sectors. Therefore, 
several publications have supported a positive relationship between higher social capital and better developed social networks within a population with economic development (e.g., Engbers \& Rubin, 2018; Fevre, 2000).

Previous evidence has recognized effect heterogeneity concerning the level of social capital and its impact in rural areas, indigenous cultures, and some countries. The findings have also supported a positive relationship between social capital and economic development. Consequently, this research suggests that cultural differences among Latin American countries should affect the relevance of social capital in new business creation and that these cultural differences are projected through their levels of economic development. Thus, the following hypothesis is proposed:

H3: The impact of social capital on nascent venture varies among Latin American countries with different levels of economic development.

\section{Materials and methods}

\section{Sample}

To achieve the research objective, this study analyses 26,611 valid responses, with 13,021 from men and 13,590 from women, from the GEM Adult Population Survey (APS) collected in 2015 (Global Entrepreneurship Monitor, n.d.). Answers obtained from residents of Latin America are selected-specifically from residents of Argentina, Brazil, Chile, Colombia, Ecuador, Guatemala, Mexico, Panama, Peru, Puerto Rico, and Uruguay. The people surveyed belong to the adult population aged 18 and older, with 41 being the average age. All respondents have a nascent, early-stage, or established venture; likewise, they cannot participate in entrepreneurship while being a dependent, student, unemployed or retired worker. A total of 7631 persons in the sample fall within the group of new entrepreneurs. The APS methodology supports the sample's representativeness based on the population characteristics in the countries studied.

\section{Measurement of variables}

Questions or statements from the APS are selected to evaluate self-entrepreneurship, respondents' perception of the value that their social environment attributes to entrepreneurship, and contacts with nearby entrepreneurs. Countries' economic development is evaluated through GDP per capita adjusted by purchasing power parity (PPP) in 2018 using International Monetary Fund (IMF) data (2018). The 2018 PPP-adjusted GDP per capita levels in United States dollars (US\$) declared by the IMF for the countries analysed are as follows: Argentina $=21,528$, Brazil $=16,199$, Chile $=25,667$, Colombia $=17,406$, Ecuador $=11,864$, Guatemala $=8429, \quad$ Mexico $=20,616$, Peru $=13,993$, Puerto Rico $=38,350$ and Uruguay $=23,571$.

Table 1 describes the selected questions and statements from the APS, their scale of measurement, and the theoretical basis that supports their contribution to this research. Gender is included as a control variable. This demographic condition has been widely studied in entrepreneurship research (e.g., Santos et al., 2016; Shahriar, 2018) and has also been analysed as an attribute that conditions motivations, attitudes, and behaviours among Latin American entrepreneurs (e.g., Bernat et al., 2017; Villasana et al., 2016). 
Table 1 Questions and affirmations used in the analysis

\begin{tabular}{|c|c|c|c|}
\hline Question or affirmation & Theoretical basis & $\begin{array}{l}\text { Examples of previous } \\
\text { uses }\end{array}$ & Measurement \\
\hline $\begin{array}{l}\text { Nascent entrepreneur: Are } \\
\text { you, alone or with others, } \\
\text { now trying to start a new } \\
\text { independent firm? }\end{array}$ & $\begin{array}{l}\text { Global Entrepreneurship } \\
\text { Monitor's definition of } \\
\text { emerging entrepreneur } \\
\text { (Bosma \& Kelley, 2018) }\end{array}$ & $\begin{array}{l}\text { Delmar and Davidsson } \\
\text { (2000). Davidsson and } \\
\text { Honig (2003). Carter et al. } \\
\text { (2003). Hoogendoorn } \\
\text { (2016) }\end{array}$ & $\begin{array}{l}\text { Dummy } \\
\text { Dichotomous: yes or no }\end{array}$ \\
\hline $\begin{array}{l}\text { Do you know anyone who } \\
\text { started a business in the } \\
\text { last two years? }\end{array}$ & $\begin{array}{l}\text { Allows measurement of } \\
\text { the social relationship of a } \\
\text { person with other entre- } \\
\text { preneurs, which facilitates } \\
\text { recognition of opportuni- } \\
\text { ties }\end{array}$ & $\begin{array}{l}\text { Ramos-Rodriguez et al. } \\
\text { (2010), Minniti (2010), } \\
\text { Wyrwich et al. (2016), Shim } \\
\text { and Kim (2018) }\end{array}$ & $\begin{array}{l}\text { Dummy } \\
\text { Dichotomous: yes or no }\end{array}$ \\
\hline $\begin{array}{l}\text { Do you have the knowl- } \\
\text { edge, skills, and experience } \\
\text { needed to start a new } \\
\text { business? }\end{array}$ & $\begin{array}{l}\text { Consistent with definitions } \\
\text { of self-concept (Gecas, } \\
\text { 1982) and self-efficacy } \\
\text { (Bandura, 1989) }\end{array}$ & $\begin{array}{l}\text { De Clercq and Arenius } \\
\text { (2006), Levie et al. (2009) }\end{array}$ & $\begin{array}{l}\text { Dummy } \\
\text { Dichotomous: yes or no }\end{array}$ \\
\hline $\begin{array}{l}\text { In your country, most peo- } \\
\text { ple consider starting a new } \\
\text { business to be a desirable } \\
\text { career }\end{array}$ & $\begin{array}{l}\text { Description of social norm } \\
\text { obtained by observing the } \\
\text { actions of others (Manning, } \\
\text { 2009) }\end{array}$ & $\begin{array}{l}\text { Teruel and De Wit (2017), } \\
\text { Bacq et al. (2016) }\end{array}$ & $\begin{array}{l}\text { Dummy } \\
\text { Dichotomous: yes or no }\end{array}$ \\
\hline $\begin{array}{l}\text { In your country, people } \\
\text { who start a successful busi- } \\
\text { ness receive a high level of } \\
\text { status and respect }\end{array}$ & $\begin{array}{l}\text { Description of social norm } \\
\text { obtained by observing the } \\
\text { actions of others (Manning, } \\
\text { 2009) }\end{array}$ & $\begin{array}{l}\text { Akola (2008), Menéndez } \\
\text { et al. (2018) }\end{array}$ & $\begin{array}{l}\text { Dummy } \\
\text { Dichotomous: yes or no }\end{array}$ \\
\hline $\begin{array}{l}\text { In your country, you often } \\
\text { see stories in the media or } \\
\text { on the Internet about suc- } \\
\text { cessful entrepreneurs }\end{array}$ & $\begin{array}{l}\text { Description of social norm } \\
\text { obtained by observing the } \\
\text { actions of others (Manning, } \\
\text { 2009) }\end{array}$ & $\begin{array}{l}\text { Hindle and Klyver (2007) } \\
\text { Akola (2008) }\end{array}$ & $\begin{array}{l}\text { Dummy } \\
\text { Dichotomous: yes or no }\end{array}$ \\
\hline
\end{tabular}

\section{Data analysis}

Logistic regressions are performed and odds ratios and $p$-values analysed to test the significance of the coefficients on the independent variables. Moreover, the Chi-square test is estimated to measure the regressions' goodness of fit, and the pseudo- $R^{2}$ parameter is used to calculate the percentage variance explained on the dependent variable. The analysis is carried out separately for the countries studied to determine differences in the odds ratio levels and their statistical significance. Then, each country's regression coefficients are scaled by its 2018 PPP-adjusted GDP per capita estimates from the IMF (2018).

In the estimation of regressions, the observations are weighted by the distribution of age and gender of the countries studied to improve the representativeness of the analyses. The logistic regression model estimated with the maximum likelihood method is presented below:

$$
\begin{aligned}
\text { He } / \text { She is Nascent Entrepreneur }= & \beta 0+\beta 1 \times \text { Knows an Entrepreneur } \\
& +\beta 2 \times \text { Positive Self }- \text { perceptions } \\
& +\beta 3 \times \text { Desirable Career } \\
& +\beta 4 \times \text { Status and Respect } \\
& +\beta 5 \times \text { Entrepreneurs in Media. }
\end{aligned}
$$




\section{Results}

\section{Overall and by gender}

In the analysis of the independent variables' impact on participation in nascent ventures, the results show that most coefficients are significant, with $p$-values lower than 0.05 or 0.01. The only variables not significant to the women's group are the perceptions that entrepreneurship is a desirable career and that successful entrepreneurs receive publicity in the media. The logistic regression models also present adequate goodness of fit, with $P>\mathrm{Chi}^{2}$ values equal to 0.00 . The magnitude of the effects, considering the odds ratio values obtained, shows that self-perceived knowledge, skills, and experiences have the highest impact on the probability of participating in a nascent enterprise. Moreover, the odds ratio coefficients associated with knowing another entrepreneur who created a new business less than 2 years before stand out. The gender-differentiated analysis shows similar and significant odds ratios for men and women. Some coefficients are slightly higher for women and vice versa. For example, self-perceived knowledge, skills, and experience have a slightly higher impact in women than in men. Table 2 presents the findings.

\section{Comparative analysis across countries}

The results of the comparative analysis among selected Latin American countries are presented in Table 3. This table describes the odds ratios and their significance as well as the pseudo- $R^{2}$ values of the logistic regressions. All regressions display adequate goodness of fit with $99 \%$ confidence, with $P>\mathrm{Chi}^{2}$ values less than 0.01 . Similarly, the results in Table 2 show that variables with a higher impact on nascent entrepreneurship creation are self-perceived skills, knowledge, experience in entrepreneurship and knowing another person who recently started a business. Although these two independent variables are significant for all South American countries, the three countries that express the greatest odds ratio magnitudes are Uruguay, Argentina, and Chile. On the other hand, Brazil and Peru show lower effect sizes. The pseudo- $R^{2}$ values obtained are in the interval $5.5 \%$ to $12.8 \%$; specifically, this parameter is higher in the countries with greater odds ratios associated with self-perceptions and knowing other entrepreneurs.

Table 2 Total and gender analysis

\begin{tabular}{|c|c|c|c|c|c|c|}
\hline & \multicolumn{2}{|l|}{ Total } & \multicolumn{2}{|l|}{ Men } & \multicolumn{2}{|l|}{ Women } \\
\hline & Odds ratio & $P>|z|$ & Odds ratio & $P>|z|$ & Odds ratio & $P>|z|$ \\
\hline Knows an entrepreneur & 2.07 & 0.00 & 2.12 & 0.00 & 1.97 & 0.00 \\
\hline Positive self-perceptions & 3.60 & 0.00 & 3.51 & 0.00 & 3.60 & 0.00 \\
\hline Desirable career & 1.07 & 0.04 & 1.09 & 0.04 & 1.05 & 0.33 \\
\hline Status and respect & 1.19 & 0.00 & 1.16 & 0.00 & 1.20 & 0.00 \\
\hline Entrepreneurs in media & 1.08 & 0.02 & 1.11 & 0.01 & 1.05 & 0.25 \\
\hline Constant & 0.09 & 0.00 & 0.10 & 0.00 & 0.09 & 0.00 \\
\hline Observations & 26,611 & & 13,021 & & 13,590 & \\
\hline$P>\mathrm{Chi}^{2}$ & 0.000 & & 0.000 & & 0.000 & \\
\hline Pseudo- $R^{2}$ & 0.090 & & 0.087 & & 0.105 & \\
\hline
\end{tabular}




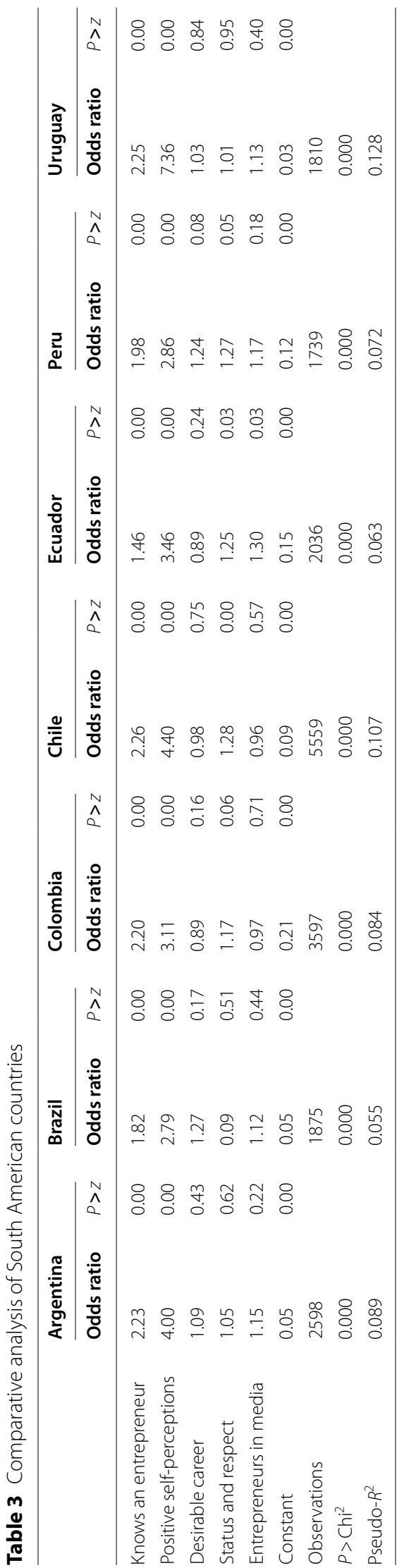


Table 4 Comparative analysis of Central and North American countries

\begin{tabular}{|c|c|c|c|c|c|c|}
\hline & \multicolumn{2}{|l|}{ Guatemala } & \multicolumn{2}{|l|}{ Mexico } & \multicolumn{2}{|l|}{ Puerto Rico } \\
\hline & Odds ratio & $P>|z|$ & Odds ratio & $P>|z|$ & Odds ratio & $P>|z|$ \\
\hline Knows an entrepreneur & 2.16 & 0.00 & 1.89 & 0.00 & 4.35 & 0.00 \\
\hline Positive self-perceptions & 3.96 & 0.00 & 2.68 & 0.00 & 7.07 & 0.00 \\
\hline Desirable career & 0.89 & 0.67 & 1.14 & 0.16 & 0.75 & 0.25 \\
\hline Status and respect & 0.89 & 0.42 & 1.36 & 0.00 & 1.14 & 0.43 \\
\hline Entrepreneurs in media & 1.00 & 0.99 & 1.24 & 0.01 & 1.15 & 0.46 \\
\hline Constant & 0.09 & 0.00 & 0.11 & 0.00 & 0.02 & 0.00 \\
\hline Observations & 2067 & & 3580 & & 1750 & \\
\hline$P>\mathrm{Chi}^{2}$ & 0.000 & & 0.000 & & 0.000 & \\
\hline Pseudo- $R^{2}$ & 0.093 & & 0.100 & & 0.180 & \\
\hline
\end{tabular}

Moreover, Table 4 shows the results for Central American countries and Mexico in North America. The regressions are also significant with $99 \%$ confidence, with the parameter $P>\mathrm{Chi}^{2}=0.00$. The coefficients linked with the self-perceptions and knowing another entrepreneur stand out for Puerto Rico; the pseudo- $R^{2}$ parameter for this country also shows the highest magnitude (18\%). For Mexico, the relevance of the social evaluation of entrepreneurs' status and the dissemination of information in the media is significant according to the p-values obtained. The pseudo- $R^{2}$ interval ranges from $9.3 \%$ to $18.0 \%$.

The odds ratio comparison of the variables with the highest magnitudes in the countries studied is presented in Fig. 1. Specifically, self-perception levels and knowing another entrepreneur are displayed. These results highlight the differences in magnitudes of Puerto Rico, Uruguay, Chile, and Argentina over those of the other countries.

When economic development is incorporated, it is possible to recognize that the countries with the highest 2018 PPP-adjusted GDP per capita (Uruguay: US\$ 23,571; Puerto Rico: US\$ 38,350; Chile: US\$ 25,667; and Argentina: US\$ 21,528) show higher odds ratios associated with self-perceptions and social capital. In the case of statements related to social norms, although differences in significance and magnitude appear, it is not possible to connect them to higher or lower levels of GDP per capita. Therefore, the evidence validates Hypothesis 1 and Hypothesis 3 of the research. Hypothesis 2 is rejected since no differences in social norms linked to countries' income levels are observed.

Finally, Fig. 2 shows the relation between the pseudo- $R^{2}$ and GDP per capita across countries. Consistent with the odds ratio results, the pseudo- $R^{2}$ values of countries with higher PPP-adjusted GDP per capita (Uruguay, Puerto Rico and Chile) stand out, with pseudo- $R^{2}$ indicators of $12.8 \%, 18 \%$, and $10.7 \%$. These three countries also show a greater relevance of self-perceptions and contact with other entrepreneurs. The fact that the impact of the selected psychological and social factors explains more than $10 \%$ of the variance in start-up participation indicates that in these countries, perceptions of oneself as an entrepreneur, overall social perceptions of entrepreneurs, and belonging to networks of entrepreneurs are especially relevant variables from a comparative perspective. The exception to this finding is Mexico, which has a pseudo- $R^{2}$ of $10 \%$ and the fifthhighest GDP per capita (US\$ 20,616). 


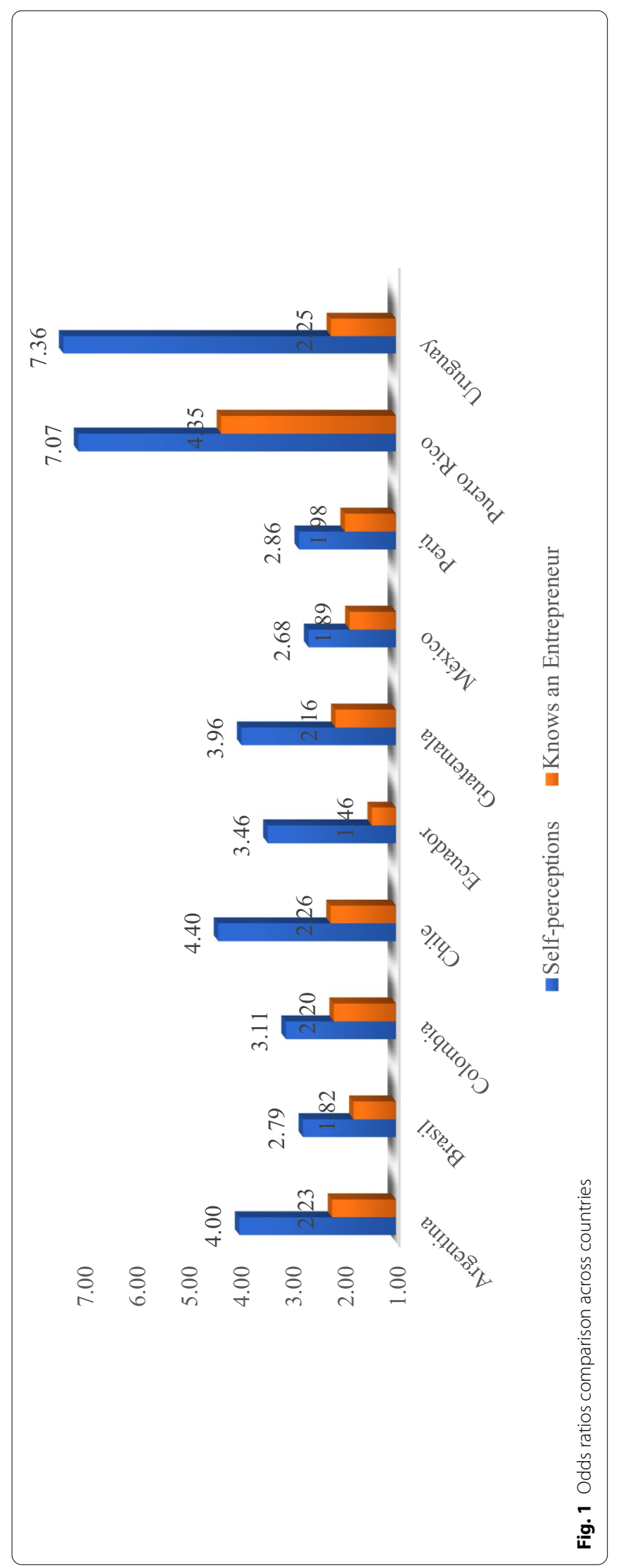




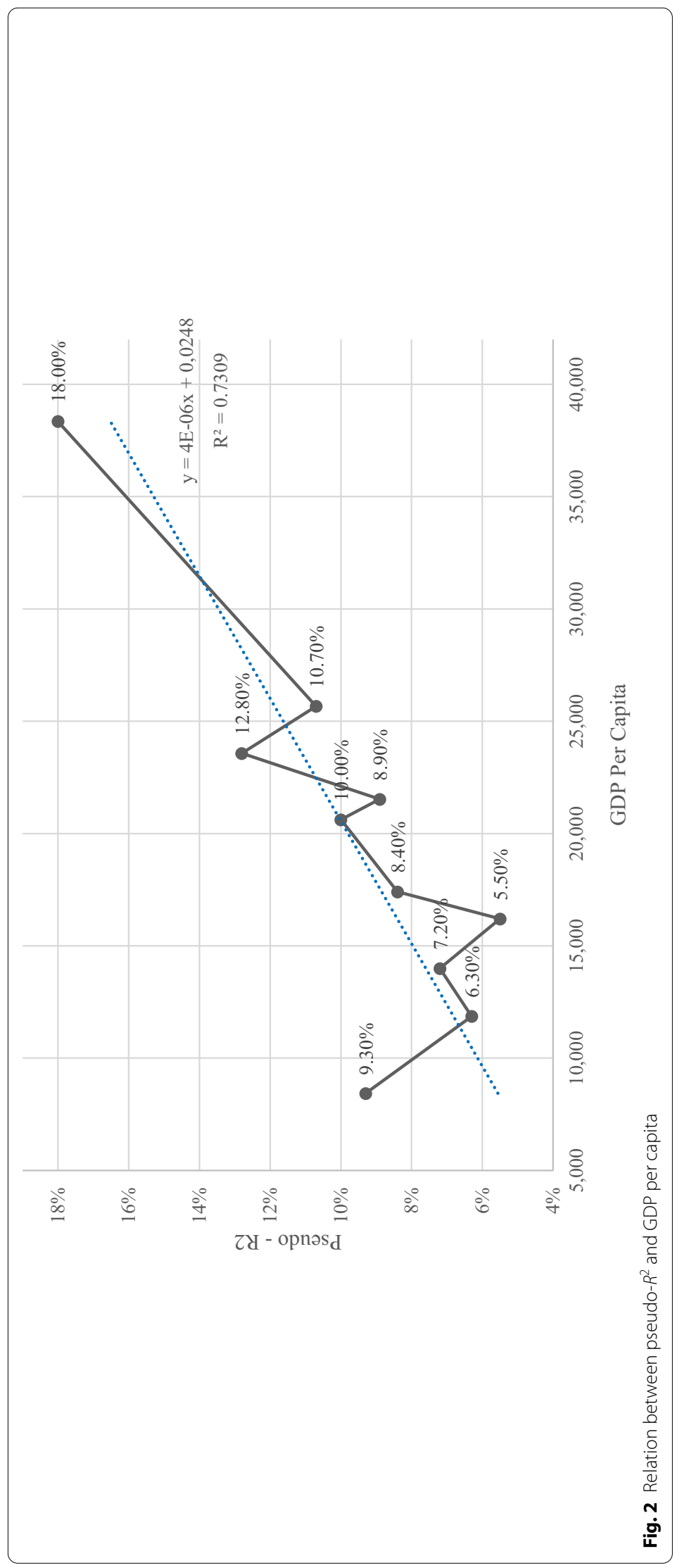




\section{Discussion and conclusions}

This research documents that self-efficacy, perceptions of subjective norms, and social references in entrepreneurship significantly affect the probability of participating in nascent entrepreneurship in the Latin American countries studied. The results allow us to extend the knowledge validated in other contexts to different countries in South, Central, and North America. The findings are consistent with previous evidence published by several authors regarding the influence of self-efficacy on entrepreneurial intention (e.g., Fuller et al., 2018), the relevance of subjective norms (e.g., Utami, 2017), and the contribution of entrepreneurial networks (e.g., Hayter, 2016).

The study provides new findings for Latin America and specifically shows that in countries with higher economic development levels measured by GDP per capita, selfperceptions of entrepreneurial capabilities and the availability of social capital or networks have a greater impact on new business creation. Additionally, the psychological and social qualities analysed explain different proportions of participation in new ventures, since only for Puerto Rico, Uruguay and Chile does the percentage of the variance explained for the dependent variable exceed $10 \%$. This percentage is similar to the results of studies that have measured the pseudo- $R^{2}$ in other continents; for example, Álvarez et al. (2012) focused on female entrepreneurship in Spain, showing pseudo- $R^{2}$ parameters in a range of $0.10-0.15$.

Moreover, the results indicate that the relationship between self-perceptions, social capital, and the creation of new enterprises varies with economic development level, which is linked to cultural differences, extending the understanding of variables incorporated in models of entrepreneurial behaviour. According to previous evidence that relates culture with economic activities and development (Bond \& Smith, 1996; Inglehart \& Baker, 2000), it is possible to argue that a greater impact of self-perceptions and social capital in countries with higher economic development, could be linked with divergent worldviews expressed in attitudes towards the family's role in work, task distributions and tendencies towards individualism or collectivism.

In practical terms, identifying the importance of psychological and social conditions and their impact on nascent enterprises' creation contributes to better management of financial, human, technological, and infrastructure resources. Therefore, this study could support the effectiveness and efficiency of interventions to strengthen entrepreneurship in these countries. For example, in Puerto Rico, self-perceptions are the variable with the greatest influence; hence, government institutions, private companies, and universities should address this attribute, prioritizing persons with lower self-perceptions, to enhance the creation of new ventures.

\section{Limitations and future research}

The analysis was carried out in relation to participation in nascent ventures only; it would also be possible to conduct a comparative analysis of entrepreneurial intent and total early-stage entrepreneurial activity (TEA). Although not presented in this paper, analyses were carried out with respect to both entrepreneurial intention and TEA, with results consistent with the presented findings presented on nascent ventures. Additional limitations are that this paper measures only 11 out of 20 Latin American countries and 
lacks a longitudinal analysis of time variations. However, the number of countries analysed is greater than $50 \%$ of the total, and cultural, psychological, and social conditions tend to be stable over time, which justifies a cross-sectional study. Moreover, the study's objective is to compare the importance of self-perceptions, relationships with other entrepreneurs, and social appreciation of entrepreneurship, not to analyse cultural traits that could explain the origin of such differences. Future research could deepen the investigation of cultural and social aspects of countries to explore their causes.

\section{Abbreviations}

APS: The Adult Population Survey; GEM: Global Entrepreneurship Monitor; GDP: Gross domestic product; IMF: International Monetary Fund; PPP: Purchasing power parity; TEA: Total index of early entrepreneurial activity; US\$: United States dollar.

\section{Acknowledgements}

Not applicable.

\section{Authors' contributions}

GBV conceived and designed the investigation, analysed and interpreted the data, and wrote the original draft. The authors read and approved the final manuscript.

Funding

This research did not receive any specific grant from funding agencies in the public, commercial, or not-for-profit sectors.

\section{Availability of data and materials}

The datasets generated and/or analysed during the current study are available in the GEM repository [https://www. gemconsortium.org/data/sets?id=aps].

\section{Declarations}

Competing interests

The author declares that he has no competing interests.

Received: 28 October 2020 Accepted: 19 October 2021

Published online: 30 October 2021

\section{References}

Acs, Z. J., Szerb, L., \& Autio, E. (2016). Global Entrepreneurship and Development Index 2015. Springer International Publishing (Springer Briefs in Economics). https://doi.org/10.1007/978-3-319-26730-2

Aguirre Mas, C., \&Vauro Desiderio, R. (2009). Autoestima y Autoeficacia de los Chilenos. Ciencia \& Trabajo, 11(32), 111-116.

Ajzen, I. (1991). The theory of planned behavior. Organizational Behavior and Human Decision Processes, 50(2), 179-211. https://doi.org/10.1016/0749-5978(91)90020-t

Akola, E. (2008). Entrepreneurship at Later Life-Intentions, Motivations and Perceptions of Entrepreneurship Among Aging Population. In ICSB World Conference Proceedings, 1-23. https://search-proquest-com.pucdechile.idm.oclc org/docview/192410551?pq-origsite=gscholar (Accessed: 9 January 2020)

Al-Jubari, I., Hassan, A., \& Liñán, F. (2019). Entrepreneurial intention among University students in Malaysia: integrating self-determination theory and the theory of planned behavior. International Entrepreneurship and Management Journal, 15(4), 1323-1342. https://doi.org/10.1007/s11365-018-0529-0

Alshebami, A., Al-Jubari, I., Alyoussef, I., \& Raza, M. (2020). Entrepreneurial education as a predicator of community college of Abqaiq students' entrepreneurial intention. Management Science Letters, 10(15), 3605-3612. https://doi.org/10. 5267/j.msl.2020.6.033

Álvarez, C., Noguera, M., \& Urbano, D. (2012). Condicionantes del entorno y emprendimiento femenino. Un estudio cuantitativo en España. Economía Industrial, 383, 43-52.

Asante, E. A., \& Affum-Osei, E. (2019). Entrepreneurship as a career choice: the impact of locus of control on aspiring entrepreneurs opportunity recognition. Journal of Business Research, 98, 227-235. https://doi.org/10.1016/j.jbusres. 2019.02 .006

Bacq, S., Hartog, C., \& Hoogendoorn, B. (2016). Beyond the moral portrayal of social entrepreneurs: an empirical approach to who they are and what drives them. Journal of Business Ethics, 133(4), 703-718. https://doi.org/10.1007/ s10551-014-2446-7

Bandura, A. (1989). Regulation of cognitive processes through perceived self-efficacy. Developmental Psychology, 25(5), 729-735. https://doi.org/10.1037/0012-1649.25.5.729

Bandura, A. (2001). Social cognitive theory: an agentic perspective. Annual Review of Psychology, 52(1), 1-26. https://doi. org/10.1146/annurev.psych.52.1.1

Banks, D. L., \& Hengartner, N. (2008). Social Networks, in Encyclopedia of Quantitative Risk Analysis and Assessment. John Wiley \& Sons, Ltd. https://doi.org/10.1002/9780470061596.risk0667 
Barrera C., \& Rodriguez, L. F. (2017). Identificación de los factores críticos y de éxito alrededor de la dinámica empresarial colombiana de los jóvenes emprendedores. Universidad de La Salle. https://ciencia.lasalle.edu.co/administracion_ de_empresas/1464/ (Accessed: 27 December 2019)

Batjargal, B. (2003). Social capital and entrepreneurial performance in Russia: a longitudinal study. Organization Studies, 24(4), 535-556. https://doi.org/10.1177/0170840603024004002

Batjargal, B. (2007). Comparative social capital: networks of entrepreneurs and venture capitalists in China and Russia. Management and Organization Review, 3(3), 397-419. https://doi.org/10.1111/j.1740-8784.2007.00080.x

Bellò, B., Mattana, V., \& Loi, M. (2018). The power of peers. International Journal of Entrepreneurial Behavior \& Research, 24(1), 214-233. https://doi.org/10.1108/ijebr-07-2016-0205

Bernat, L. F., Lambardi, G., \& Palacios, P. (2017). Determinants of the entrepreneurial gender gap in Latin America. Small Business Economics, 48(3), 727-752. https://doi.org/10.1007/s11187-016-9789-7

Bicchieri, C., \& Muldoon, R. (2011). Social Norms. In Edward N. Zalta (Eds.) The Stanford Encyclopedia of Philosophy (Winter 2018 Edition). https://plato.stanford.edu/archives/win2018/entries/social-norms (Accessed: 08 September 2020)

Bizri, R. M. (2017). Refugee-entrepreneurship: a social capital perspective. Entrepreneurship \& Regional Development, 29(9-10), 847-868. https://doi.org/10.1080/08985626.2017.1364787

Bond, R., \& Smith, P. B. (1996). Culture and conformity: a meta-analysis of studies using Aschs (1952b, 1956) line judgment task. Psychological Bulletin, 119(1), 111-137. https://doi.org/10.1037/0033-2909.119.1.111

Bosma, N., \& Kelley, D. (2018). Global entrepreneurship monitor global report. Babson College.

Boyd, N. G., \& Vozikis, G. S. (1994). The influence of self-efficacy on the development of entrepreneurial intentions and actions. Entrepreneurship Theory and Practice, 18(4), 63-77. https://doi.org/10.1177/104225879401800404

Bravo, S., \& Quijano, S. E. (2015). Las dimensiones de capital social entre emprendedores incubados. Sotavento MBA, 26, 34-41. https://doi.org/10.18601/01233734.n26.04

Buttice, V., Colombo, M. G., \& Wright, M. (2017). Serial crowdfunding, social capital, and project success. Entrepreneurship Theory and Practice, 41(2), 183-207. https://doi.org/10.1111/etap.12271

Cardon, M. S., \& Kirk, C. P. (2015). Entrepreneurial passion as mediator of the self-efficacy to persistence relationship. Entrepreneurship Theory and Practice, 39(5), 1027-1050. https://doi.org/10.1111/etap.12089

Carter, N. M., Gartner, W. B., Shaver, K. G., \& Gatewood, E. J. (2003). The career reasons of nascent entrepreneurs. Journal of Business Venturing, 18(1), 13-39. https://doi.org/10.1016/s0883-9026(02)00078-2

Chandran, D., \& Aleidi, A. (2018). Analyzing the Influence of Gender Stereotypes and Social Norms on Female IT Entrepreneurial Intention in Saudi Arabia. In Proceedings of the 51st Hawaii International Conference on System Sciences. https://doi.org/10.24251/hicss.2018.519

Chen, C., Greene, P. G., \& Crick, A. (1998). Does entrepreneurial self-efficacy distinguish entrepreneurs from managers? Journal of Business Venturing, 13(4), 295-316. https://doi.org/10.1016/s0883-9026(97)00029-3

Chen, G., Gully, S. M., \& Eden, D. (2001). Validation of a new general self-efficacy scale. Organizational Research Methods, 4(1), 62-83. https://doi.org/10.1177/109442810141004

Christoforou, A. (2017). Social capital and local development in European rural areas: theory and empirics. In Social Capital and Local Development (43-60). Palgrave Macmillan. https://doi.org/10.1007/978-3-319-54277-5_3

Davidsson, P. (2006). Nascent Entrepreneurship: empirical studies and developments. Foundations and Trends in Entrepreneurship, 2(1), 1-76. https://doi.org/10.1561/0300000005

Davidsson, P., \& Honig, B. (2003). The role of social and human capital among nascent entrepreneurs. Journal of Business Venturing, 18(3), 301-331. https://doi.org/10.1016/s0883-9026(02)00097-6

De Carolis, D. M., \& Saparito, P. (2006). Social capital, cognition, and entrepreneurial opportunities: a theoretical framework. Entrepreneurship Theory and Practice, 30(1), 41-56. https://doi.org/10.1111/j.1540-6520.2006.00109.x

de Vries, H., Dijkstra, M., \& Kuhlman, P. (1988). Self-efficacy: the third factor besides attitude and subjective norm as a predictor of behavioural intentions. Health Education Research, 3(3), 273-282. https://doi.org/10.1093/her/3.3.273

Delmar, F., \& Davidsson, P. (2000). Where do they come from? Prevalence and characteristics of nascent entrepreneurs. Entrepreneurship and Regional Development, 12(1), 1-23. https://doi.org/10.1080/089856200283063

Engbers, T. A., \& Rubin, B. M. (2018). Theory to practice: policy recommendations for fostering economic development through social capital. Public Administration Review, 78(4), 567-578. https://doi.org/10.1111/puar.12925

Ephrem, A. N., Namatovu, R., \& Basalirwa, E. M. (2019). Perceived social norms, psychological capital and entrepreneurial intention among undergraduate students in Bukavu. Education Training, 61(7-8), 963-983. https://doi.org/10. 1108/et-10-2018-0212

Fafchamps, M. (2011). Development, social norms, and assignment to task. Proceedings of the National Academy of Sciences, 108(4), 21308-21315. https://doi.org/10.1073/pnas.1019457108

Farooq, M. S., Salam, M., ur Rehman, S., Fayolle, A., Jaafar, N., \& Ayupp, K. (2018). Impact of support from social network on entrepreneurial intention of fresh business graduates. Education Training, 60(4), 335-353. https://doi.org/10.1108/ et-06-2017-0092

Fenech, R., Baguant, P., \& Ivanov, D. (2019). Entrepreneurial attitudes, self-efficacy, and subjective norms amongst female Emirati entrepreneurs. International Journal of Entrepreneurship, 23(1), 1-11.

Fevre, R. (2000). Socializing social capital: Identity, the transition to work, and economic development. In S. Baron, J. Field, \&T. Schulle (Eds.), Social capital: critical perspectives (pp. 94-110). Oxford University Press.

Foley, D. (2008). Does culture and social capital impact on the networking attributes of indigenous entrepreneurs? Journal of Enterprising Communities: People and Places in the Global Economy, 2(3), 204-224. https://doi.org/10.1108/ 17506200810897204

Fornoni, M., \& Foutel, M. (2004) El Círculo Virtuoso: capital social—emprendedores, in El emprendedor innovadory la creación de empresas I+D+I (pp. 421-431). Universitat de Valencia, Spain. https://doi.org/10.1108/1750620081 0897204

Fuller, B., Liu, Y., Bajaba, S., Marler, L. E., \& Pratt, J. (2018). Examining how the personality, self-efficacy, and anticipatory cognitions of potential entrepreneurs shape their entrepreneurial intentions. Personality and Individual Differences, 125, 120-125. https://doi.org/10.1016/.jpaid.2018.01.005 
Global Entrepreneurship Monitor. (n.d.). Entrepreneurial Behaviour and Attitudes. https://www.gemconsortium.org/data/ sets?id=aps (Accessed 10 Jan. 2020)

Gómez Legarda, L. F. (2019). Incidencia del financiamiento en las distintas etapas del ciclo de vida de los emprendimientos en el Ecuador. Repositorio Digital, Universidad Católica de Santiago de Guayaquil, Ecuador. http://repositorio.ucsg. edu.ec/handle/3317/13961

Greenwald, A. G., Banaji, M. R., Rudman, L. A., Farnham, S. D., Nosek, B. A., \& Mellott, D. S. (2002). A unified theory of implicit attitudes, stereotypes, self-esteem, and self-concept. Psychological Review, 109(1), 3-25. https://doi.org/10.1037/ 0033-295x.109.1.3

Guzmán-Alfonso, C., \& Guzmán-Cuevas, J. (2012). Entrepreneurial intention models as applied to Latin America. Journal of Organizational Change Management, 25(5), 721-735. https://doi.org/10.1108/09534811211254608

Hayter, C. S. (2016). Constraining entrepreneurial development: a knowledge-based view of social networks among academic entrepreneurs. Research Policy, 45(2), 475-490. https://doi.org/10.1016/j.respol.2015.11.003

Hindle, K., \& Klyver, K. (2007). Exploring the relationship between media coverage and participation in entrepreneurship: initial global evidence and research implications. International Entrepreneurship and Management Journal, 3(2), 217-242. https://doi.org/10.1007/s11365-006-0018-8

Hoogendoorn, B. (2016). The prevalence and determinants of social entrepreneurship at the macro level. Journal of Small Business Management, 54, 278-296. https://doi.org/10.1111/jsbm.12301

Hsu, D. K., Burmeister-Lamp, K., Simmons, S. A., Foo, M. D., Hong, M. C., \& Pipes, J. D. (2019). "I know I can, but I dont fit": perceived fit, self-efficacy, and entrepreneurial intention. Journal of Business Venturing, 34(2), 311-326. https://doi. org/10.1016/j.jbusvent.2018.08.004

Inglehart, R., \& Baker, W. E. (2000). Modernization, cultural change, and the persistence of traditional values. American Sociological Review, 65(1), 19-51. https://doi.org/10.2307/2657288

Inglehart, R., \& Carballo, M. (2008). Existe Latinoamérica? Un análisis global de diferencias transculturales. Perfiles Latinoamericanos, 16(31), 13-38.

Inglehart, R., \& Welzel, C. (2005). Modernization, cultural change, and democracy: the human development sequence. Cambridge University Press.

International Monetary Fund (2018). Report for Selected Countries and Subjects. World Economic Outlook Database, 2018. https://www.imf.org/external/pubs/ft/weo/2018/01/weodata/index.aspx

Kautonen, T., van Gelderen, M., \& Tornikoski, E. T. (2013). Predicting entrepreneurial behaviour: a test of the theory of planned behaviour. Applied Economics, 45(6), 697-707. https://doi.org/10.1080/00036846.2011.610750

Kim, P. H., \& Aldrich, H. E. (2005). Social capital and entrepreneurship. Foundations and Trends in Entrepreneurship, 1(2), 55-104. https://doi.org/10.1561/0300000002

Krauss, C., Bonomo, A., \& Volfovicz, R. (2018). Modelo predictivo de la intención emprendedora universitaria en Latinoamérica. Journal of Technology Management \& Innovation, 13(4), 84-93. https://doi.org/10.4067/s0718-27242 018000400084

Krueger, N. F., \& Carsrud, A. L. (1993). Entrepreneurial intentions: applying the theory of planned behaviour. Entrepreneurship \& Regional Development, 5(4), 315-330. https://doi.org/10.1080/08985629300000020

Krueger, N. F., Reilly, M. D., \& Carsrud, A. L. (2000). Competing models of entrepreneurial intentions. Journal of Business Venturing, 15(5-6), 411-432. https://doi.org/10.1016/s0883-9026(98)00033-0

La Ferrara, E. (2019). Aspirations, social norms, and development. Journal of the European Economic Association, 17(6), 1687-1722. https://doi.org/10.1093/jeea/jvz057

Lecuna, A., Cohen, B., \& Chavez, R. (2017). Characteristics of high-growth entrepreneurs in Latin America. International Entrepreneurship and Management Journal, 13(1), 141-159. https://doi.org/10.1007/s11365-016-0402-y

Levie, J., Hart, M., \& Anyadike-Danes, M. (2009). The effect of business or enterprise training on opportunity recognition and entrepreneurial skills of graduates and non-graduates in the UK. In: Frontiers of Entrepreneurial Research. Babson. http://publications.aston.ac.uk/id/eprint/37351/.

Levie, J., Hart, M., \& Shamsul Karim, M. (2010). Impact of Media on Entrepreneurial Intentions and Actions. Aston Business School, GEM UK project. https://assets.publishing.service.gov.uk/government/uploads/system/uploads/attac hment_data/file/32243/11-773-impact-of-media-entrepreneurial-intentions-actions.pdf

Li, T., Yang, Y. C., \& Zhang, Y. (2018). Culture, economic development, social-network type, and mortality: evidence from Chinese older adults. Social Science \& Medicine, 204, 23-30. https://doi.org/10.1016/j.socscimed.2018.03.021

Lin, N. (2017). Building a network theory of social capital. In N. Lin, K. Cook, \& R. Burt (Eds.), Social capital (pp. 3-28). Routledge.

Littlewood, D., \& Holt, D. (2018). Social entrepreneurship in South Africa: exploring the influence of environment. Business \& Society, 57(3), 525-561. https://doi.org/10.1177/0007650315613293

Loughnan, S., Kuppens, P., Allik, J., Balazs, K., De Lemus, S., Dumont, K., Gargurevich, R., Hidegkuti, I., Leidner, B., Matos, L., \& Park, J. (2011). Economic inequality is linked to biased self-perception. Psychological Science, 22(10), 1254-1258. https://doi.org/10.1177/0956797611417003

Low, M. B., \& Abrahamson, E. (1997). Movements, bandwagons, and clones: industry evolution and the entrepreneurial process. Journal of Business Venturing, 12(6), 435-457. https://doi.org/10.1016/s0883-9026(97)00001-3

Lundberg, H., \& Rehnfors, A. (2018). Transnational entrepreneurship: opportunity identification and venture creation. Journal of International Entrepreneurship, 16(2), 150-175. https://doi.org/10.1007/s10843-018-0228-5

Madrigal, B. E., Arechavala, R., \& Madrigal, R. (2012). El Emprendedor y Su Capital Social: Caso el Clúster del Software en Jalisco. Revista Internacional Administración \& Finanzas, 5(4), 107-120. https://doi.org/10.22201/fcpys.24484903e. 2019.47.69501

Manning, M. (2009). The effects of subjective norms on behaviour in the theory of planned behaviour: a meta-analysis British Journal of Social Psychology, 48(4), 649-705. https://doi.org/10.1348/014466608×393136

Martinez Dy, A. (2020). Not all entrepreneurship is created equal: theorising entrepreneurial disadvantage through social positionality. European Management Review. https://doi.org/10.1111/emre.12390

Mason, C., \& Brown, R. (2014). Entrepreneurial ecosystems and growth oriented entrepreneurship. Final report to OECD, Paris $30(1), 77-102$. 
McGee, J. E., \& Peterson, M. (2019). The long-term impact of entrepreneurial self-efficacy and entrepreneurial orientation on venture performance. Journal of Small Business Management, 57(3), 720-737. https://doi.org/10.1111/jsbm. 12324.

McGee, J. E., Peterson, M., Mueller, S. L., \& Sequeira, J. M. (2009). Entrepreneurial self-efficacy: refining the measure. Entrepreneurship Theory and Practice, 33(4), 965-988. https://doi.org/10.1111/j.1540-6520.2009.00304.x

Menéndez, M. M., Mendieta, I. B., Saltos, B. P., Ulloa, G. G., \& Bastidas, J. V. (2018). Factores que Influyen en el Emprendimiento y su Incidencia en el Desarrollo Económico del Ecuador. Revista Ciencias Sociales y Económicas, 2(1), 1-22. https://doi.org/10.18779/csye.v2i1.263

Midgley, J., \& Livermore, M. (1998). Social capital and local economic development: implications for community social work practice. Journal of Community Practice, 5(1-2), 29-40. https://doi.org/10.1300/j125v05n01_03

Minniti, M. (2010). Female entrepreneurship and economic activity. European Journal of Development Research, 22(3), 294-312. https://doi.org/10.1057/ejdr.2010.18

Moriano, J. A., Gorgievski, M., Laguna, M., Stephan, U., \& Zarafshani, K. (2012). A cross-cultural approach to understanding entrepreneurial intention. Journal of Career Development, 39(2), 162-185. https://doi.org/10.1177/0894845310 384481

Mueller, S. L., \& Conway Dato-on, M. (2013). A cross cultural study of gender-role orientation and entrepreneurial self-efficacy. International Entrepreneurship and Management Journal, 9(1), 1-20. https://doi.org/10.1007/ s11365-011-0187-y

Neergaard, H., \& Madsen, H. (2004). Knowledge intensive entrepreneurship in a social capital perspective. Journal of Enterprising Culture, 12(2), 105-125. https://doi.org/10.1142/s0218495804000063

Neumeyer, X., Santos, S. C., Caetano, A., \& Kalbfleisch, P. (2019). Entrepreneurship ecosystems and women entrepreneurs: a social capital and network approach. Small Business Economics, 53(2), 475-489. https://doi.org/10.1007/ s11187-018-9996-5

Newman, A., Obschonka, M., Schwarz, S., Cohen, M., \& Nielsen, I. (2019). Entrepreneurial self-efficacy: a systematic review of the literature on its theoretical foundations, measurement, antecedents, and outcomes, and an agenda for future research. Journal of Vocational Behavior, 110, 403-419. https://doi.org/10.1016/j.jvb.2018.05.012

Nguyen, C. H., \& Nordman, C. J. (2018). Household entrepreneurship and social networks: panel data evidence from Vietnam. The Journal of Development Studies, 54(4), 594-618. https://doi.org/10.1080/00220388.2017.1303668

Nowiński, W., Haddoud, M. Y., Lančarič, D., Egerová, D., \& Czeglédi, C. (2019). The impact of entrepreneurship education, entrepreneurial self-efficacy and gender on entrepreneurial intentions of university students in the Visegrad countries. Studies in Higher Education, 44(2), 361-379. https://doi.org/10.1080/03075079.2017.1365359

Obschonka, M., \& Stuetzer, M. (2017). Integrating psychological approaches to entrepreneurship: the entrepreneurial personality system (EPS). Small Business Economics, 49(1), 203-231. https://doi.org/10.1007/s11187-016-9821-y

OECD. (2016). Síntesis y recomendaciones de política. In Startup América Latina 2016, 17-28. Organisation for economic cooperation and development, Estudios del Centro de Desarrollo. https://doi.org/10.1787/9789264265141-5-es

Onder, M., \& Nyadera, I. N. (2019). The role of non-economic drivers in development planning: the case of South Korea and Turkey. International Journal of Public Administration, 43(4), 283-293. https://doi.org/10.1080/01900692.2019. 1628057

Ostgaard, T. A., \& Birley, S. (1996). New venture growth and personal networks. Journal of Business Research, 36(1), 37-50. https://doi.org/10.1016/0148-2963(95)00161-1

Palivos, T. (2001). Social norms, fertility and economic development. Journal of Economic Dynamics and Control, 25(12), 1919-1934. https://doi.org/10.1016/s0165-1889(00)00008-7

Peterman, N. E., \& Kennedy, J. (2003). Enterprise education: Influencing students' perceptions of entrepreneurship. Entrepreneurship Theory and Practice, 28(2), 129-144. https://doi.org/10.1046/j.1540-6520.2003.00035.x.

Pinillos, M. J., \& Reyes, L. (2011). Relationship between individualist-collectivist culture and entrepreneurial activity: evidence from Global Entrepreneurship Monitor data. Small Business Economics, 37(1), 23-37. https://doi.org/10. 1007/s11187-009-9230-6

Piperopoulos, P., \& Dimov, D. (2015). Burst bubbles or build steam? Entrepreneurship education, entrepreneurial selfefficacy, and entrepreneurial intentions. Journal of Small Business Management, 53(4), 970-985. https://doi.org/10. $1111 / j s b m .12116$

Ramos-Rodriguez, A. R., Medina-Garrido, J. A., Lorenzo-Gómez, J. D., \& Ruiz-Navarro, J. (2010). What you know or who you know? The role of intellectual and social capital in opportunity recognition. International Small Business Journal: Researching Entrepreneurship, 28(6), 566-582. https://doi.org/10.1177/0266242610369753

Rehan, F., Block, J. H., \& Fisch, C. (2019). Entrepreneurship in Islamic communities: how do Islamic values and Islamic practices influence entrepreneurship intentions? SSRN Electronic Journal. https://doi.org/10.2139/ssrn.3405196

Reynolds, P. (1994). Autonomous firm dynamics and economic growth in the United States, 1986-1990. Regional Studies, 28(4), 429-442. https://doi.org/10.1080/00343409412331348376

Rodríguez, J. G., \& Sánchez-Riofrío, A. (2017). ICTs and poverty in Latin America. Iconos Revista De Ciencias Sociales. https:// doi.org/10.17141/iconos.57.2017.2095

Roundy, P. T., Bradshaw, M., \& Brockman, B. K. (2018). The emergence of entrepreneurial ecosystems: a complex adaptive systems approach. Journal of Business Research, 86, 1-10. https://doi.org/10.1016/j.jbusres.2018.01.032

Sanabria Rangel, P. E., Morales Rubiano, M. E., \& Ortiz Riaga, C. (2015). Interacción Universidad y entorno: marco para el emprendimiento. Educación y Educadores, 18(1), 111-134. https://doi.org/10.5294/edu.2015.18.1.7

Santos, F. J., Roomi, M. A., \& Liñán, F. (2016). About gender differences and the social environment in the development of entrepreneurial intentions. Journal of Small Business Management, 54(1), 49-66. https://doi.org/10.1111/jsbm. 12129

Schmutzler, J., Andonova, V., \& Diaz-Serrano, L. (2019). How context shapes entrepreneurial self-efficacy as a driver of entrepreneurial intentions: a multilevel approach. Entrepreneurship Theory and Practice, 43(5), 880-920. https://doi. org/10.1177/1042258717753142

Shahriar, A. Z. M. (2018). Gender differences in entrepreneurial propensity: evidence from matrilineal and patriarchal societies. Journal of Business Venturing, 33(6), 762-779. https://doi.org/10.1016/j.jbusvent.2018.04.005 
Shim, J., \& Kim, J. (2018). Estimating country-level social network density and supportive surroundings by simulation. Journal of Business Venturing Insights, 9, 24-31. https://doi.org/10.1016/j.jbvi.2017.12.002

Solesvik, M. Z. (2017). A cross-national study of personal initiative as a mediator between self-efficacy and entrepreneurial intentions. Journal of East-West Business, 23(3), 215-237. https://doi.org/10.1080/10669868.2017.1306821

Stam, E., Suddle, K., Hessels, S. J. A., \& van Stel, A. (2006). Los emprendedores con potencial de crecimiento y el desarrollo económico: políticas públicas de apoyo a los emprendedores (Vol. 62, pp. 124-149). Revista Vasca de Economía.

Stephan, U., \& Uhlaner, L. M. (2010). Performance-based vs socially supportive culture: a cross-national study of descriptive norms and entrepreneurship. Journal of International Business Studies, 41(8), 1347-1364. https://doi.org/10. 1057/jibs.2010.14

Stuart, T. E., \& Sorenson, O. (2005). Social networks and entrepreneurship. In Alvarez, S. A., Agarwal, R., \& Sorenson, O (Eds.), Handbook of entrepreneurship research (pp. 233-252). Springer, Boston, MA. https://doi.org/10.1007/0-38723622-8_11.

Teruel, M., \& de Wit, G. (2017). Determinants of high-growth firms: why do some countries have more high-growth firms than others? In J. Bonnet, M. Dejardin, \& D. Gacía-Péres-De-Lema (Eds.), Exploring the entrepreneurial society (pp. 46-58). Edward Elgar Publishing. https://doi.org/10.4337/9781783472666.00010

Trigilia, C. (2001). Social capital and local development. European Journal of Social Theory, 4(4), 427-442. https://doi.org/ $10.1177 / 13684310122225244$

Ucbasaran, D., Shepherd, D. A., Lockett, A., \& Lyon, S. J. (2013). Life after business failure: the process and consequences of business failure for entrepreneurs. Journal of Management, 39(1), 163-202. https://doi.org/10.1177/0149206312 457823

Utami, C. W. (2017). Attitude, subjective norm, perceived behaviour, entrepreneurship education and self-efficacy toward entrepreneurial intention university student in Indonesia. European Research Studies Journal, 20(2A), 475-495.

Van Ness, R. K., \& Seifert, C. F. (2016). A theoretical analysis of the role of characteristics in entrepreneurial propensity. Strategic Entrepreneurship Journal, 10(1), 89-96. https://doi.org/10.1002/sej.1205

Villasana, M., Alcaraz-Rodríguez, R., \& Alvarez, M. M. (2016). Examining entrepreneurial attributes of Latin American female university students. Gender and Education, 28(1), 148-166. https://doi.org/10.1080/09540253.2015.1093100

Wang, J. H., Chang, C. C., Yao, S. N., \& Liang, C. (2016). The contribution of self-efficacy to the relationship between personality traits and entrepreneurial intention. Higher Education, 72(2), 209-224. https://doi.org/10.1007/ s10734-015-9946-y

Wennberg, K., Pathak, S., \& Autio, E. (2013). How culture moulds the effects of self-efficacy and fear of failure on entrepreneurship. Entrepreneurship \& Regional Development, 25(9-10), 756-780. https://doi.org/10.1080/08985626.2013. 862975

Wilson, F., Kickul, J., \& Marlino, D. (2007). Gender, entrepreneurial self-efficacy, and entrepreneurial career intentions: implications for entrepreneurship education. Entrepreneurship Theory and Practice, 31(3), 387-406. https://doi.org/ $10.1111 / j .1540-6520.2007 .00179 . x$

Wu, J., \& Si, S. (2018). Poverty reduction through entrepreneurship: incentives, social networks, and sustainability. Asian Business and Management, 17(4), 243-259. https://doi.org/10.1057/s41291-018-0039-5

Wyrwich, M., Stuetzer, M., \& Sternberg, R. (2016). Entrepreneurial role models, fear of failure, and institutional approval of entrepreneurship: a tale of two regions. Small Business Economics, 46(3), 467-492. https://doi.org/10.1007/ s11187-015-9695-4

\section{Publisher's Note}

Springer Nature remains neutral with regard to jurisdictional claims in published maps and institutional affiliations.

\section{Submit your manuscript to a SpringerOpen ${ }^{\circ}$ journal and benefit from:}

Convenient online submission

- Rigorous peer review

- Open access: articles freely available online

High visibility within the field

Retaining the copyright to your article

Submit your next manuscript at $\boldsymbol{\Delta}$ springeropen.com 